\title{
Hubungan Pola Asuh Orang Tua Dengan Masalah Mental Emosional Remaja
}

\author{
Yeni Devita \\ Sekolah Tinggi Ilmu Kesehatan Payung Negeri Pekanbaru \\ Correspondence email: yenidevita@payungnegeri.ac.id
}

\begin{abstract}
Abstrak. Hasil penelitian WHO dan Riset Kesehatan Dasar tahun 2013 didapatkan remaja mengalami masalah mental emosional.Salah satu faktor penyebab masalah mental emosional remaja adalah pola asuh orang tua. Penelitian ini bertujuan unt uk mengetahui hubungan pola asuh orang tua dengan masalah mental emosional remaja.Desain penelitian deskriptif analitik, pendekatan cross sectional, sampel 266 remaja. Hasil penelitian didapatkan rerata pola asuh otoriter adalah 27,31, pola asuh demokratis 30,30 , dan pola asuh permisif 29,05 . Pola asuh yang dominan adalah pola asuh demokratis.Masalah mental emosional remaja termasuk pada kategori borderline dengan rerata skor 18-19.Rerata umur remaja 16-17 tahun. Jenis kelamin remaja 54,9\% perempuan. Pendidikan remaja $82 \%$ pendidikan tinggi. Pekerjaan orang tua $61,7 \%$ pekerjaan formal. Pendidikan orang tua $63,5 \%$ berpendidikan tinggi. Tingkat sosial ekonomi 58,3\% rendah. Ada hubungan antara pola asuh otoriter, demokratis, permisif, umur remaja, pekerjaan orang tua, pendidikan orang tua, dan tingkat sosial ekonomi dengan masalah mental emosional remaja.Variabel yang paling berpengaruh dengan masalah mental mental emosional remaja adalah pola asuh permisif.Saran untuk keilmuan keperawatan jiwa lebih mengembangkan edukasi terkait pola asuh orang tua yang dapat diterapkan untuk mencegah terjadinya masalah mental emosional remaja.
\end{abstract}

Kata Kunci: Masalah Mental Emosional; Pola Asuh Orang Tua; Remaja

Abstrack. The results of WHO research and Basic Health Research in 2013 found that adolescents experience mental emotional problems. One of the factors causing adolescent mental emotional problems is parenting. This study aims to determine the relationship of parenting parents with adolescent mental emotional problems. Descriptive analytic research design, cross sectional approach, a sample of 266 adolescents. The results showed the average authoritarian parenting was 27.31, democratic parenting 30.30, and permissive parenting 29.05. The dominant parenting pattern is democratic parenting. Adolescent mental emotional problems are included in the borderline category with an average score of 18-19. The average age of adolescents is 1617 years. The sex of adolescents is $54.9 \%$ female. Teen education $82 \%$ higher education. Parents' occupations $61.7 \%$ formal employment. Parents' education is $63.5 \%$ highly educated. The socioeconomic level is $58.3 \%$ low. There is a relationship between authoritarian parenting, democratic, permissive, adolescent age, parental work, parental education, and socioeconomic level with adolescent mental emotional problems. The most influential variables with mental emotional mental adolescent problems are permissive parenting. Suggestions for science psychiatric nursing further develops education related to parental care that can be applied to prevent adolescent emotional emotional problems.

Keywords: Emotional Mental Problems; Parenting Parents; Teenager

\section{PENDAHULUAN}

Masa remaja merupakan masa transisi dari masa anak-anak menuju dewasa. Masa remaja adalah suatu fase perkembangan yang dinamis dan mengalami perubahan serta persoalan dalam kehidupan seorang individu. Perubahan tersebut meliputi perubahan fisik, perilaku, kognitif, biologis, dan emosi. Persoalan pada remaja meliputi persoalan sosial, aspek emosional, aspek fisik dan keluarga, sekolah, dan kelompok teman sebaya (Stuart, 2013). Perubahan dan persoalan yang terjadi dalam kehidupan jika tidak dapat dikontrol dengan baik dapat memicu terjadinya masalah mental emosional pada remaja.

Masalah mental emosional merupakan suatu keadaaan yang mengidentifikasikan individu mengalami suatu perubahan emosional sehingga dapat berkembang menjadi keadaan patologis apabila terus berlanjut, sehingga perlu dilakukan antisipasi agar kesehatan jiwa tetap terjaga (Kusuma, 2014). Masalah mental emosional remaja dapat menghambat, merintangi,atau mempersulit remaja dalam usahanya menyesuaikan diri dengan lingkungan dan pengalaman-pengalamannya. Masalah mental emosional mencakup gejala emosional, masalah perilaku, hiperaktivitas/inatensi, masalah hubungan dengan teman sebaya, dan perilaku prososial (Diananta, 2012).

Hasil penelitian WHO didapatkan bahwa 1 dari 5 anak yang berusia kurang dari 16 tahun mengalami masalah mental emosional. Anak yang berusia 4-15 tahun yang mengalami masalah mental emosional sebanyak 104 dari 1000 anak. Angka kejadian tersebut makin tinggi pada kelompok usia diatas 15 tahun, yaitu 140 dari 1000 anak. Remaja di Amerika dilaporkan mengalami masalah perilaku dengan menggunakan tembakau, melakukan hubungan seksual, dan mengggunakan obat-obatan terlarang sebelum usia 15 tahun dan mengalami masalah perilaku sosial di usia 15 tahun keatas (McGue, 2005). Penelitian Stadler (2010) 
melaporkan $20 \%$ remaja di Jerman mengalami masalah dengan teman sebaya, hal ini menunjukkan bahwa remaja beresiko mengalami masalah mental emosional.

Riset Kesehatan Dasar (Riskesdas) pada tahun 2013 memperlihatkanprevalensi gangguan mental emosional pada orang Indonesia dengan usia diatas 15 tahun adalah 6,0\%. Ikatan Dokter Anak Indonesia (IDAI, 2010) melaporkan sebanyak $80 \%$ remaja Indonesia berusia 11-15 tahun dikatakan pernah menunjukkan perilaku beresiko seperti berkelakuan buruk disekolah, penyalahgunaan zat, serta perilaku antisosial (mencuri, berkelahi, atau membolos) dan 50\% diantara mereka juga menunjukkan adanya perilaku beresiko tinggi lainnya seperti mengemudi dalam keadaan mabuk, melakukan hubungan seksual tanpa kontrasepsi, dan perilaku kriminal yang bersifat minor.

Badan Pusat Statistik (BPS) menunjukkan trend kenakalan dan kriminalitas remaja di Indonesia mulai dari kekerasan fisik, kekerasan seksual dan kekerasan psikis meningkat. Pada tahun 2007 tercatat sebanyak 3145 remaja usia $\leq 18$ tahun menjadi pelaku tindak kriminal, tahun 2008 dan 2009 meningkat menjadi 3280 hingga 4123 remaja (BPS, 2010). Data yang diperoleh dari SurveiDataKesehatanIndonesia(SDKI, 2012) dilaporkan remaja usia 15-19 tahun telah menunjukkan perilaku menyimpang dan masalah emosional. Sebanyak $8,9 \%$ remaja putri dan $74,4 \%$ remaja putra telah merokok, $3,5 \%$ remaja putri dan $30,2 \%$ remaja putra telah minum minuman beralkohol, $0,1 \%$ remaja putri dan $2,8 \%$ remaja putra pernah menggunakan obat terlarang, $0,7 \%$ remaja putri dan $4,5 \%$ remaja putra pernah melakukan hubungan seksual, sebanyak $12,8 \%$ dilaporkan remaja telah menikah, dan $30 \%$ remaja putri pernah melakukan tindakan aborsi (Lukmansyah \& Andini, 2012).

Survei yang dilakukan Federasi Kesehatan Mental Indonesia (Fekmi) menemukan bahwa para remaja telah mengenal tempat maksiat, perilaku minum minuman keras, merokok, dan narkoba dan sudah muncul pada remaja awal. Hasil survei pada tahun 2003 yang diadakan di 10 kota besar Indonesia, yaitu Medan, Padang, Jakarta, Bandung, Semarang, Yogyakarta, Surabaya, Banjarmasin, Denpasar, dan Ujung Pandang menunjukkan bahwa 54\% remaja mengaku pernah berkelahi, $87 \%$ berbohong, $8,9 \%$ pernah mencoba narkoba, 28\% merasa kekerasan sebagai hal biasa, dan 24\% pernah membaca buku porno.Data dari Penelitian dan Pengembangan (LITBANG) juga menunjukkan di Jakarta, pada tahun 2010 tercatat 128 kasus tawuran antar pelajar. Angka tersebut meningkat lebih dari $100 \%$ pada 2011, yakni 330 kasus tawuran yang menewaskan 82 pelajar. Pada bulan Januari-Juni 2012, telah terjadi 139 tawuran yang menewaskan 12 orang pelajar (Lukmansyah \& Andini, 2012).

Data epidemiologis dilaporkan $34,39 \%$ dari pengunjung puskesmas di kecamatan Tambora berusia 5-15 tahun menunjukkan gangguan mental emosional.
Ditinjau dari proporsi penduduk, $40 \%$ dari total populasi terdiri atas anak dan remaja usia 0-16 tahun, ternyata 7$14 \%$ dari populasi anak dan remaja mengalami gangguan kesehatan jiwa, sementara itu $11,7 \%$ anak prasekolah berisiko tinggi mengalami gangguan perilaku(Hamid 2009). Penelitian yang dilakukan oleh Hartanto (2011) di Semarang diperoleh hasil bahwa sekitar $9,1 \%$ remaja SMP di kota Semarang mempunyai masalah mental emosional. Penelitian Wiguna (2010) menunjukkan proporsi terbesar dari masalah mental emosional pada anak dan remaja di Jakarta adalah masalah hubungan dengan teman sebaya $54,81 \%$, dan masalah emosional $42,2 \%$, sedangkan untuk remaja lebih banyak mengalami masalah emosi $(33,55)$. Garland (2000) dalam Wiguna (2010) melaporkan bahwa 33,6\% anak yang datang ke pusat pelayanan kesehatan jiwa dengan masalah mental emosional. Penelitian yang dilakukan oleh Dewi (2012), $43 \%$ remaja terpengaruh oleh teman sebaya dan $53,9 \%$ remaja meniru teman sebaya dalam hal persepsi yang sama, $56 \%$ remaja menunjukkan perilaku seksual beresiko, dan ada pengaruh teman sebaya dengan perilaku seksual remaja.

Tahun 2012-2013 di kota Pekanbaru Provinsi Riau juga terdapat kasus kekerasan yang dilakukan remaja yang bergabung dalam satu kelompok geng motor. Tahun 2012 tercatat sebanyak 25 kasus pidana yang dilakukan gengmotor; Januari-Mei tahun 2013 tercatat 8 kasus. Tindakan kriminal yang merekalakukan antara lain pencurian dengan kekerasan, pengrusakan, penganiayaan, hingga pemerkosaan. Kasat Reskrim Polresta Pekanbaru mengatakan banyak siswa pelajar tingkat SMP dan SMA menjadi anggota geng motor yang sudah didoktrin untuk melakukan tindak kriminal seperti penjambretan, penodongan, pencurian, penganiayaan berat, perusakan dan pengancaman, ini dibuktikan pada bulan Mei 2013 polisi menangkap dua anggota geng motor di salah satu Sekolah Menegah Kejuruan Pekanbaru (Anggoro, 2013).

Masalah mental emosional pada remajayang tidak ditindaklanjuti dan tidak diselesaikan dengan baik akan berdampak negatif terhadap tahap perkembangan remaja kelak terutama pematangan karakternya, meningkatnya masalah perilaku dan tidak jarang memicu terjadinya gangguan mental emosional yang dapat berupa perilaku beresiko tinggi, contohnya yaitu remaja yang merokok beresiko tinggi untuk ketergantungan terhadap nikotin, meminum alkohol pada usia kurang dari 15 tahun beresiko tinggi untuk menjadi seorang pecandu alkohol (alcoholism), perilaku pelanggaran hukum pada masa remaja diramalkan akan menyebabkan terjadinya gangguan kepribadian antisosial, melakukan hubungan seksual pada remaja dapat meningkatkan resiko terjadinya kehamilan yang tidak diinginkan(McGue, 2005). Masalah-masalah perilaku seperti kehamilan remaja, penyakit seksual yang ditularkan, gangguan makan, penyalahgunaan obat dan alkohol, merokok, masalah emosional, dan sebagainya jika tidak dideteksi 
sedini mungkin akan mempengaruhi tahap perkembangan remaja, kehidupan pribadi, keluarga, bangsa dan negara dimasa yang akan datang.

Masalah mental emosional pada remaja dipengaruhi oleh interaksi antara faktor risiko dan faktor protektif. Faktor risiko meliputi faktor individu, keluarga, sekolah, peristiwa hidup, dan faktor sosial. Faktor protektif meliputi karakter / watak yang positif, lingkungan keluarga yang suportif, lingkungan sosial yang berfungsi sebagai sistem pendukung untuk memperkuat upaya penyesuaian diri remaja, keterampilan sosial yang baik, serta tingkat intelektual yang baik (Wiguna, 2010). Salah satu faktor yang turut berperan dalam perkembangan mental emosional pada remaja adalah keluarga. Keluarga memberikan dasar pembentukan kepribadian, tingkah laku, watak, moral dan pendidikan anak. Faktor-faktor yang mempengaruhi mental emosional remaja dilingkungan keluarga adalah pola asuh orang tua, kondisi keluarga, moral dalam keluarga, dan hubungan dengan saudara kandung. Faktor dalam keluarga yang mempunyai peran penting untuk dapat mewujudkan keluarga yang sejahtera dan mencegah masalah mental emosional adalah penerapan pola asuh orang tua (Sipahutar, 2009).

Pola asuh merupakan suatu proses mendidik, membimbing, dan mendisiplinkan serta melindungi anak untuk mencapai kedewasaan sesuai dengan norma dalam masyarakat. Pola asuh orang tua sangat mempengaruhi bagaimana anak berperilaku dan bentuk kepribadian anak secara keseluruhan. Tipe pola asuh orang tua terbagi atas tiga tipe yaitu : pola asuh demokratis, pola asuh otoriter, dan pola asuh permisif. Masing-masing pola asuh tersebut mempunyai dampak bagi perkembangan anak dan remaja (Santrock, 2007).

Pola asuh demokratis merupakan pola asuh yang mendorong remaja untuk bebas tetapi tetap memberikan batasan dan mengendalikan tindakan - tindakan mereka. Komunikasi verbal timbal balik bisa berlangsung dengan bebas dan orang tua bersikap hangat dan bersifat membesarkan hati remaja. Pola asuh otoriter adalah pola asuh yang membatasi dan bersifat menghukum yang mendesak remaja untuk mengikuti petunjuk orang tua. Orang tua yang bersifat otoriter membuat batasan dan kendali yang tegas terhadap remaja dan hanya melakukan sedikit komunikasi verbal. Pola asuh permisif adalah pola asuh dimana orang tua tidak begitu terlibat dengan remaja. Orang tua tipe permisif tidak menuntut ataupun mengendalikan remaja (Santrock, 2007).

Setiap pola asuh menghasilkan karakteristik yang berbeda-beda pada masing-masing anak. Pola asuh demokratis menghasilkan karakteristik anak yang mandiri, dapat mengontrol diri, mempunyai hubungan baik dengan teman, mampu menghadapi stress, mempunyai minat terhadap hal-hal baru dan kooperatif terhadap orang lain. Pola asuh otoriter akan menghasilkan karakteristik anak yang penakut, pendiam, tertutup, tidak berinisiatif, gemar menentang, suka melanggar norma, berkepribadian lemah, cemas, dan menarik diri. Pola asuh permisif akan menghasilkan karakteristik anak yang impulsive, agresif, tidak patuh, kurang mandiri, mau menang sendiri, kurang percaya diri dan kurang matang secara sosial.Pola asuh mempunyai peranan yang sangat penting bagi perkembangan mental emosional anak. Penerapan pola asuh untuk setiap orang tua dapat berbeda-beda. Menurut Baumrind (1971 dalam Santrock, 2007) dalam kehidupan sehari-hari kebanyakan orang tua menggunakan kombinasi dari kesemua pola asuh yang ada, akan tetapi satu jenis pola asuh akan terlihat lebih dominan daripada pola asuh lainnya dan sifatnya hampir stabil sepanjang waktu.

Hasil penelitian Stadler (2010) menunjukkan ada hubungan antara pola asuh orang tua dengan masalah kesehatan mental dan perilaku pada anak di negara Jerman seperti masalah hubungan dengan teman sebaya. Stadler mengatakan ada resiko tinggi terjadinya masalah kesehatan mental pada remaja usia 15-18 tahun jika dukungan dari orang tua mereka rendah terhadap perkembangannya. Penelitian Turner (2009)menunjukkan bahwa pola asuh demokratisterbukti dapat meningkatkan prestasi akademik pada mahasiswa dan penelitian Konnie (2013) menunjukkan mayoritas pola asuh orang tua di Italy adalah demokratis $(68,7 \%)$, diikuti dengan pola asuh otoriter $(16,7 \%)$ dan pola asuh permisif $(14,6 \%)$. Penelitian yang dilakukan oleh Nurmagupta (2014) di Yogyakarta menunjukkan mayoritas pola asuh orang tua adalah pola asuh permisif dan ada hubungan pola asuh dengan perilaku seksual beresiko di Kabupaten Bantul Yogyakarta. Hasil penelitian Aguma (2014) menunjukkan mayoritas pola asuh orang tua di Kota Pekanbaru adalah pola asuh demokratis yaitu sebesar $37,3 \%$, diikuti dengan pola asuh otoriter $26 \%$ ), dan pola asuh permisif $(18,1 \%)$. Hasil penelitiannya menunjukkan ada hubungan antara pola asuh orang tua dengan perilaku seksual remaja.

Survei pendahuluan yang dilakukan oleh peneliti dengan cara mengobservasi kelakuan dan tingkah laku remaja di lingkungan Kelurahan Tuah Karya Kecamatan Tampan Kota Pekanbaru di Bulan Mei 2015 terlihat bahwa hampir seluruh remaja laki-laki terlihat senang berkumpul dengan teman sebayanya sambil mengisap sebatang rokok. Remaja yang menggunakan kendaraan sepeda motor terlihat ugal-ugalan dan suka ngebut dalam berkendara. Beberapa remaja terlihat berbicara dengan kata-kata kasar dan kotor. Hasil wawancara dengan delapanremaja didapatkan lima dari delapanremaja tersebut mengatakan mereka terkadang mempunyai masalah dengan teman sebaya mereka, bahkan empatdari mereka pernah terlibat perkelahian antar pelajar. Empat remaja mengatakan bahwa orang tua mereka tidak pernah melarang mereka berteman dengan siapapun, dantigaremaja perempuan mengatakan mereka sering dimarahi oleh orang tua mereka jika pulang sekolah 
telat. Hal-hal seperti diatas menunjukkan masalah perilaku remaja yang dapat menyebabkan masalah mental emosional mereka.

\section{METODE}

Jenis penelitian yang digunakan dalam penelitian ini adalah jenis penelitian kuantitatif. Jenis penelitian yang digunakan bersifat deskriptif analitik dengan desain cross sectional. Penelitian ini dilakukan untuk membuktikan ada atau tidaknya hubungan secara statistik antarapola asuh orang tua dengan masalah mental emosional remaja di Kelurahan Tuah Karya Kecamatan Tampan Kota Pekanbaru Provinsi Riau. Populasi dalam penelitian ini adalah seluruh remaja yang tinggal di Kelurahan Tuah Karya Kecamatan Tampan Kota Pekanbaru Provinsi Riau pada bulan Mei 2015 yang berjumlah 11.477 orang (Laporan Penduduk Kelurahan Tuah Karya Kecamatan Tampan Kota Pekanbaru Mei 2015). Sampel yang terlibat dalam penelitian ini adalah sebanyak 266 remaja. Pada penelitian ini, peneliti mengambil sampel dengan tehnik purposive sampling, yaitu tehnik penentuan sampel dengan pertimbangan tertentu berdasarkan kriteria inklusi dan eksklusi. Kriteria inklusi dan eksklusi pada penelitian ini diantaranya :

1. Kriteria inklusi :

a. Remaja yang berusia $10-19$ tahun

b. Remaja yang tinggal menetap di wilayah Kelurahan Tuah Karya Kecamatan Tampan Kota Pekanbaru

c. Masih memiliki orang tua dan tinggal bersama orang tua

d. Bersedia menjadi responden

2. Kriteria eksklusi :

a. Memiliki keterbatasan fisik atau gangguan mental

b. Telah menikah

c. Responden mengundurkan diri dari proses penelitian

Penelitian ini dilakukan di Kelurahan Tuah Karya Kecamatan Tampan Kota Pekanbaru Provinsi Riau. Penelitian ini dilaksanakan dari bulan Februari sampai Oktober 2015. Prinsip etik yang menjadi dasar penelitian ini adalah anonimity (kerahasaian), confidentially, beneficience, dan justice. Instrumen dalam penelitian ini menggunakan 2 kuesioner, yaituStrenght and Difficulties Questionnaire (SDQ) untuk menilai masalah mental emosional remaja dan kuesioner pola asuh orang tua (Parental Care Style Quesioner). Analisa data yang digunakan pada penelitian ini meliputi analisa univariat, bivariat, dan multivariat. Uji statistik yang digunakan pada penelitian ini adalah uji spearman rank, mannwhitney test dan regresi linear.

\section{HASIL DAN PEMBAHASAN}

Tabel 1. Gambaran Skor Pola Asuh Otoriter, Demokratis, Otoriter Pada Remaja $(n=266)$

\begin{tabular}{lccccc}
\hline \multicolumn{1}{c}{ Variabel } & Mean & SD & $\begin{array}{c}\text { Min }- \\
\text { Mak }\end{array}$ & f & \% \\
\hline $\begin{array}{l}\text { Pola Asuh } \\
\text { Otoriter }\end{array}$ & 27,31 & 3,770 & $12-38$ & 53 & 19,9 \\
$\begin{array}{l}\text { Pola Asuh } \\
\begin{array}{l}\text { Demokratis } \\
\text { Pola Asuh }\end{array}\end{array}$ & 30,30 & 3,685 & $17-39$ & 169 & 63,5 \\
Permisif & 29,05 & 5,233 & $16-43$ & 44 & 16,5 \\
\hline
\end{tabular}

Hasil analisis menunjukkan bahwa orang tua menggunakan seluruh pola asuh kepada remajanya, namun rata-rata orang tua lebih cenderung menggunakan pola asuh demokratis untuk mendidik anaknya. Hasil analisis menunjukkan rata-rata pola asuh otoriter adalah 27,31 dengan persentase $19,9 \%$ (53 orang). Rata-rata pola asuh demokratis adalah 30,30 dengan persentase $63,5 \%$ (169 orang). Rata-rata pola asuh permisif adalah 29,05 dengan persentase $16,5 \%$ (44 orang).

Tabel 2. Gambaran Skor Masalah Mental Emosional Pada Remaja (n=266)

\begin{tabular}{lcccc}
\hline \multicolumn{1}{c}{ Variabel } & Mean & SD & $\begin{array}{c}\text { Min - } \\
\text { Mak }\end{array}$ & CI 95\% \\
\hline $\begin{array}{l}\text { Masalah Mental } \\
\text { Emosional Remaja }\end{array}$ & 18,45 & 5,821 & $4-29$ & $17,75-19,15$ \\
\hline
\end{tabular}

Hasil analisis didapatkan rata-rata skor masalah mental emosional remaja adalah 18,45 (rentang skor 1819). Masalah mental emosional remaja termasuk kedalam kategori borderline.Dimana masalah mental emosional terdiri dari tiga kategori yaitu normal dengan skor 0-15, borderline dengan skor 16-19, dan abnormal dengan skor 20-40.

Tabel 3. Distribusi Rerata Umur Responden $(n=266)$

\begin{tabular}{ccccc}
\hline Variabel & Mean & SD & Min - Mak & CI 95\% \\
\hline Umur (tahun) & 16,63 & 1,802 & $10-19$ & $16,41-16,85$ \\
\hline
\end{tabular}

Hasil analisis didapatkan rata-rata umur responden adalah 16,63 tahun (95\% CI : 16,41 - 16,85) dengan standar deviasi 1,802 . Umur termuda adalah 10 tahun dan umur tertua adalah 19 tahun. Dari hasil estimasi interval dapat disimpulkan bahwa 95\% diyakini bahwa rata-rata umur responden adalah antara 16 - 17 tahun.

Tabel 4. Distribusi Frekuensi Karakteristik Responden $(n=266)$

\begin{tabular}{lcc}
\hline \multicolumn{1}{c}{ Variabel Karakteristik } & F & $\%$ \\
\hline Jenis Kelamin & & \\
1. Laki-Laki & 120 & 45,1 \\
2. Perempuan & 146 & 54,9 \\
Pendidikan & & \\
1. Tinggi & 218 & 82 \\
2. Rendah & 48 & 18 \\
\hline
\end{tabular}


Hasil analisis didapatkan bahwa lebih dari separuh responden berjenis kelamin perempuan dan sebagian besar responden berpendidikan tinggi (SMA-Perguruan Tinggi).

Tabel 5. Distribusi Frekuensi Karakteristik Orang Tua

\begin{tabular}{lcc}
\hline \multicolumn{1}{c}{ Variabel Karakteristik } & F & \% \\
\hline Pekerjaan Orang Tua & & \\
1. Formal & 164 & 61,7 \\
2. Non Formal & 102 & 38,3 \\
Pendidikan Orang Tua & & \\
1. Tinggi & 169 & 63,5 \\
2. Rendah & 97 & 36,5 \\
Tingkat Sosial Ekonomi & & \\
1. Rendah & 155 & 58,3 \\
2. Tinggi & 111 & 41,7 \\
\hline
\end{tabular}

Hasil analisis didapatkan bahwa lebih dari separuh orang tua responden memiliki pekerjaan formal (PNS dan Swasta), lebih dari separuh orang tua responden memiliki pendidikan tinggi (SMA dan Perguruan Tinggi), dan lebih dari separuh orang tua responden memiliki tingkatsosial ekonomi rendah.

Tabel 6. Hubungan Pola Asuh Orang Tua Otoriter, Pola Asuh Demokratis, Pola Asuh Permisif Dengan Masalah Mental Emosional Remaja $(n=266)$

\begin{tabular}{ccc}
\hline & \multicolumn{2}{c}{ Masalah Mental Emosional } \\
\hline \multirow{2}{*}{ Pola Asuh Otoriter } & $\mathrm{R}$ & $-0,171$ \\
& $\mathrm{P}$ & 0,005 \\
Pola Asuh Demokratis & $\mathrm{R}$ & $-0,308$ \\
& $\mathrm{P}$ & 0,000 \\
\multirow{2}{*}{ Pola Asuh Permisif } & $\mathrm{R}$ & 0,184 \\
& $\mathrm{p}$ & 0,003 \\
\hline
\end{tabular}

Hasil analisis spearman rank menunjukkan bahwa ada hubungan antara pola asuh otoriter, pola asuh demokratis, dan pola asuh permisif dengan masalah mental emosional remaja. Pola asuh otoriter memiliki kekuatan korelasi sangat lemah dan arah korelasi negatif, yang artinya dengan menurunnya pola asuh otoriter akan meningkatkan masalah mental emosional remaja. Pola asuh demokratis memiliki kekuatan lemah dan arah korelasi negatif, yang artinya dengan menurunnya pola asuh demokratis akan meningkatkan masalah mental emosional remaja. Pola asuh permisif memiliki arah korelasi positif, yang artinya semakin permisif pola asuh maka akan semakin tinggi masalah mental emosional remaja

Tabel 7. HubunganUmur Responden Dengan Masalah Mental Emosional Remaja $(\mathrm{n}=266)$

\begin{tabular}{lcc}
\hline & & Masalah Mental Emosional \\
\hline Umur Responden & $\mathrm{r}$ & 0,256 \\
& $\mathrm{p}$ & 0,000 \\
\hline
\end{tabular}

Hasil analisis spearman rank menunjukkan bahwa ada hubungan antara umur responden dengan masalah mental emosional remaja dengan kekuatan korelasi lemah dan arah korelasi positif, yang artinya semakin meningkat umur remaja ke remaja akhir maka akan semakin beresiko mengalami masalah mental emosional.

Tabel 8. Hubungan Jenis Kelamin dan Pendidikan Remaja Dengan Masalah Mental Emosional Remaja ( $\mathrm{n}=266)$

\begin{tabular}{lccc}
\hline & $\mathrm{N}$ & Median (Min - Mak) & $\mathrm{p}$ value \\
\hline $\begin{array}{l}\text { Jenis } \\
\text { Kelamin laki- }\end{array}$ & 120 & $19(4-29)$ & \\
$\begin{array}{l}\text { Laki } \\
\text { Jenis }\end{array}$ & 146 & $19(5-29)$ & 0,222 \\
$\begin{array}{l}\text { Kelamin } \\
\begin{array}{l}\text { Perempuan } \\
\text { Pendidikan }\end{array}\end{array}$ & 218 & $19(4-29)$ & \\
$\begin{array}{l}\text { Tinggi } \\
\text { Pendidikan } \\
\text { Rendah }\end{array}$ & 48 & $18,50(8-29)$ & 0,655 \\
\hline
\end{tabular}

Hasil analisis Mann-Whitney jenis kelamin dan pendidikan diperoleh angka significancy 0,222 dan 0,655 . Karena nilai p value $>0,05$, dapat disimpulkan bahwa tidak ada hubungan antara jenis kelamin remaja dan pendidikan remaja dengan masalah mental emosional remaja.

Tabel 9. Hubungan Pekerjaan Orang Tua, Pendidikan Orang Tua, dan Status Sosial EkonomiDengan Masalah Mental Emosional Remaja

\begin{tabular}{lccc}
\hline & $\mathrm{N}$ & $\begin{array}{c}\text { Median } \\
\text { (Min - Mak) }\end{array}$ & $\mathrm{p}$ value \\
\hline $\begin{array}{l}\text { Pekerjaan } \\
\text { Formal }\end{array}$ & 164 & $21(4-29)$ & 0,000 \\
$\begin{array}{l}\text { Non Formal } \\
\text { Pendidikan }\end{array}$ & 102 & $16(4-27)$ & \\
$\begin{array}{l}\text { Pendidikan Tinggi } \\
\text { Pendidikan Rendah }\end{array}$ & 169 & $20(4-29)$ & 0,008 \\
$\begin{array}{l}\text { Tingkat Sosial Ekonomi } \\
\text { Rendah }\end{array}$ & 97 & $18(4-29)$ & \\
Tinggi & 155 & $18(4-29)$ & 0,004 \\
& 111 & $20(4-29)$ & \\
\hline
\end{tabular}

Hasil analisis Mann-Whitney diperoleh angka significancy pada pekerjaan orang tua $(0,000)$, pendidikan orang tua $(0,008)$, dan tingkat sosial ekonomi $(0,004)$. Karena masing-masing memiliki nilai $p$ value < 0,05 , dapat disimpulkan bahwa ada hubungan antara pekerjaan orang tua, pendidikan orang tua, dan status sosial ekonomi dengan masalah mental emosional remaja. 
Tabel 10. Analisis Multivariat Pola Asuh Orang Tua, Karakteristik Responden Dan Karakteristik Orang Tua Terhadap Masalah Mental Emosional Remaja

\begin{tabular}{|c|c|c|c|c|}
\hline Langkah & $\begin{array}{r}\text { Variabel } \\
\end{array}$ & Koefesien & Koefesien Korelasi & p value \\
\hline \multirow{9}{*}{ Langkah 1} & Pola Asuh Otoriter & $-0,029$ & $-0,019$ & 0,772 \\
\hline & Pola Asuh Demokratis & $-0,337$ & $-0,213$ & 0,000 \\
\hline & Pola Asuh permisif & 0,383 & 0,344 & 0,000 \\
\hline & Umur Remaja & 0,469 & 0,145 & 0,008 \\
\hline & Jenis Kelamin & 0,676 & 0,058 & 0,275 \\
\hline & Pekerjaan Orang Tua & $-2,228$ & $-0,186$ & 0,014 \\
\hline & Pendidikan Orang Tua & 0,083 & 0,007 & 0,918 \\
\hline & Tingkat Sosial Ekonomi & 0,312 & 0,027 & 0,651 \\
\hline & Konstanta & 12,028 & & 0,012 \\
\hline \multirow{8}{*}{ Langkah 2} & Pola Asuh Otoriter & $-0,030$ & $-0,019$ & 0,768 \\
\hline & Pola Asuh Demokratis & $-0,336$ & $-0,213$ & 0,000 \\
\hline & Pola Asuh permisif & 0,383 & 0,345 & 0,000 \\
\hline & Umur Remaja & 0,469 & 0,145 & 0,007 \\
\hline & Jenis Kelamin & 0,676 & 0,058 & 0,274 \\
\hline & Pekerjaan Orang Tua & $-2,178$ & $-0,182$ & 0,004 \\
\hline & Tingkat Sosial Ekonomi & 0,307 & 0,026 & 0,656 \\
\hline & Konstanta & 12,060 & & 0,011 \\
\hline \multirow{7}{*}{ Langkah 3} & Pola Asuh Demokratis & $-0,349$ & $-0,221$ & 0,000 \\
\hline & Pola Asuh permisif & 0,379 & 0,340 & 0,000 \\
\hline & Umur Remaja & 0,471 & 0,146 & 0,007 \\
\hline & Jenis Kelamin & 0,680 & 0,058 & 0,270 \\
\hline & Pekerjaan Orang Tua & $-2,258$ & $-0,189$ & 0,002 \\
\hline & Tingkat Sosial Ekonomi & 0,303 & 0,026 & 0,659 \\
\hline & Konstanta & 11,843 & & 0,11 \\
\hline \multirow{6}{*}{ Langkah 4} & Pola Asuh Demokratis & $-0,349$ & $-0,221$ & 0,000 \\
\hline & Pola Asuh permisif & 0,380 & 0,342 & 0,000 \\
\hline & Umur Remaja & 0,482 & 0,149 & 0,005 \\
\hline & Jenis Kelamin & 0,669 & 0,057 & 0,227 \\
\hline & Pekerjaan Orang Tua & $-2,380$ & $-0,199$ & 0,000 \\
\hline & Konstanta & 12,226 & & 0,008 \\
\hline \multirow{5}{*}{ Langkah 5} & Pola Asuh Demokratis & $-0,350$ & $-2,222$ & 0,000 \\
\hline & Pola Asuh permisif & 0,379 & 0,341 & 0,000 \\
\hline & Umur Remaja & 0,473 & 0,146 & 0,006 \\
\hline & Pekerjaan Orang Tua & $-2,459$ & $-0,206$ & 0,000 \\
\hline & Konstanta & 13,593 & & 0,002 \\
\hline
\end{tabular}

Hasil analisis regresi linear menunjukkan bahwa ada empat variabel yang mempunyai nilai probabilitas kurang dari 0,05 . Keempat variabel itu yaitu pola asuh demokratis $(\mathrm{p}=0,000)$, pola asuh permisif $(\mathrm{p}=0,000)$, umur remaja $(\mathrm{p}=0,006)$, dan pekerjaan orang tua $(\mathrm{p}=0,000)$. Variabel independen yang paling dominan berpengaruh terhadap masalah mental emosional remaja dari keempat variabel tersebut adalah pola asuh permisif.Hal ini ditentukan berdasarkan koefesien korelasi variabel pola asuh permisif sebesar 0,341 yang lebih besar dari koefesien korelasi pola asuh demokratis $(-0,222)$, umur remaja $(0,146)$, dan pekerjaaan orang tua $-0,206)$.

\section{Pembahasan \\ Hubungan Pola Asuh Otoriter dengan Masalah Mental Emosional Remaja}

Hasil penelitian menunjukkan bahwa ada hubungan antara pola asuh otoriter dengan masalah mental emosional remaja. Hasil penelitian ini sejalan dengan dengan penelitian yang dilakukan oleh Yuldawati (2008) yang menunjukkan bahwa ada hubungan pola asuh otoriter dengan perilaku seksual berisiko pada remaja.Hasil penelitiannya menunjukkan remaja dengan pola asuh otoriter mempunyai peluang 3,258 kali untuk berperilaku seksual berisiko dibanding pola asuh demokratis.

Pola asuh yang cenderung memberikan kekangan, larangan, dan selalu menginterogasi tentang apa saja yang dilakukan anak-anaknya ternyata tidak berefek baik bagi perilaku anak remajanya (Fuad, 2010). Tidak jarang remaja berusaha keluar dari permasalahannya dan melarikan diri dari rumah serta memberontak terhadap apa yang dilarang oleh orang tuanya (Santrock, 2007). Semakin orang tua melarang keinginan anaknya tanpa memberi alasan yang dapat diterima dengan baik oleh anak maka akibatnya dapat berupa keinginan yang semakin besar untuk mencari tahu sendiri jawabannya (Mustansky, 2007). Jika kekangan ini terlalu kuat remaja akan semakin penasaran untuk mencoba hal-hal yang dilarang untuk upaya mencari perhatian orang tuanya. Penelitian yang dilakukan oleh Laksmiwati (2009) bahwa orang tua yang cenderung bersikap otoriter mempertinggi angka kenakalan remaja, sehingga tidak 
jarang pola asuh otoriter dapat menyebabkan masalah mental emosional pada remaja.

Hasil penelitian diperoleh arah korelasi antara pola asuh otoriter dengan masalah mental emosional remaja adalah arah negatif. Hal ini berarti semakin menurun pola asuh otoriter maka akan semakin beresiko terjadinya masalah mental emosional remaja, atau semakin otoriter pola asuh orang tua maka akan semakin sedikit resiko terjadinya masalah mental emosional pada remaja.

Berdasarkan uraian diatas dapat disimpulkan bahwa pola asuh otoriter dapat terus digunakan oleh orang tua dalam mendidik anaknya untuk menghindari terjadinya masalah mental emosional, apalagi ketika anak remajanya sudah mulai menunjukkan perilaku negatif yang beresiko terjadinya masalah mental emosional.

\section{Hubungan Pola Asuh Demokratis dengan Masalah Mental Emosional Remaja}

Hasil penelitian menunjukkan bahwa ada hubungan antara pola asuh demokratis dengan masalah mental emosional remaja. Hal ini dapat diartikan bahwa sikap demokratis orang tua dapat juga menyebabkan terjadinya masalah mental emosional bagi remaja. Hal ini sejalan dengan penelitian yang dilakukan oleh Kharie (2014) yang menunjukkan hasil bahwa remaja yang diasuh oleh orang tua yang demokratis juga menunjukkan masalah perilaku seperti merokok.

Data yang didapatkan pada penelitian yang dilakukan oleh Kharie ini ada 2 orang remaja perokok ringan dan 9 orang remaja perokok berat. Hal tersebut terjadi karena selain faktor pola asuh yang tepat terdapat juga faktor lain yang dapat membuat anak mengalami masalah perilaku seperti merokok, antara lain lingkungan, keluarga, teman sebaya, dan media sosial. Keluarga dengan perilaku merokok dapat membuat remaja juga berperilaku merokok, karena remaja cenderung meniru perilaku dari orang yang bermakna terutama keluarga.

Hoskins (2014) mengemukan bahwa para peneliti menemukan fakta orang tua yang demokratis menunjukkan pemantauan yang tinggi selama masa kanak-kanak dan sedikit menurun ketika anak mereka masuk usia remaja. Temuan ini menunjukkan bahwa orang tua yang demokratis sedikit melepaskan pemantauan mereka dalam menanggapi peningkatan tuntutan remaja untuk pengambilan keputusan secara independen. Hasil temuan ini sesuai dengan penelitian yang diperoleh bahwa arah korelasi antara pola asuh demokratis dengan masalah mental emosional remaja menunjukkan arah korelasi negatif, yang artinya semakin rendah atau semakin menurunnya pola asuh demokratis maka akan semakin tinggi / meningkat pula masalah mental emosional remaja.

Hal inilah yang dapat menyebabkan remaja dengan orang tua yang demokratis juga berisiko mengalami masalah mental emosional. Berdasarkan uraian diatas dapat disimpulkan bahwa pola asuh demokratis harus tetap dipertahankan oleh orang tua hingga anaknya mencapai usia remaja untuk menghindari remaja mengalami masalah mental emosional yang akan berdampak pada kesehatan jiwa remaja.

\section{Hubungan Pola asuh Permisif dengan Masalah Mental Emosional Remaja}

Hasil penelitian menunjukkan bahwa ada hubungan antara pola asuh permisif dengan masalah mental emosional remaja. Hasil penelitian ini sejalan dengan penelitian yang dilakukan oleh Nurmagupta (2014) yang menunjukkan bahwa ada hubungan pola asuh permisif dengan perilaku seksual berisiko pada remaja. Sikap permisif diartikan sikap orang tua yang memberikan kebebasan kepada anaknya. Kurang mau tau segala urusan anak-anaknya dan cenderung membiarkan anaknya untuk berbuat semau hatinya (Santrok, 2007).

Orang tua yang bersikap permisif terhadap pergaulan anaknya bisa saja dikarenakan orang tua takut anaknya akan bertindak diluar batas kewajaran jika anaknya dikekang, dan membuat anaknya menjadi minder dan kurang rasa percaya diri, sehingga orang tua cenderung memberikan kebebasan pada anaknya (Fuad, 2010). Berdasarkan hasil penelitian diperoleh arah korelasi antara pola asuh permisif dengan masalah mental emosional remaja adalah arah korelasi positif. Hal ini berarti bahwa semakin tinggi pola asuh permisif maka akan semakin tinggi pula masalah mental emosional remaja.

Dari hasil penelitian tersebut dapat dianalisa bahwa pola asuh permisif yang terus digunakan oleh orang tua dapat menyebabkan anak remajanya beresiko mengalami masalah mental emosional.Sikap permisif orang tua tentunya sangat mempunyai dampak yang tidak baik bagi perkembangan remaja, baik perkembangan emosional, maupun perkembangan psikososialnya. Orang tua cenderung tidak menegur atau memperingatkan anak apabila anak sedang dalam bahaya, dan sangat sedikit bimbingan yang diberikan oleh mereka. Dari uraian diatas dapat disimpulkan bahwa semakin permisif orang tua dalam mendidik anaknya maka akan semakin beresiko anak remajanya mengalami masalah mental emosional, untuk itu pola asuh permisif tidak baik dijadikan sebagai pola asuh yang dominan dalam mendidik anak.

\section{Hubungan Umur Responden dengan Masalah Mental Emosional Remaja}

Hasil penelitianmenunjukkan rata-rata umur responden adalah 16-17 tahun dan ada hubungan antara umur responden dengan masalah mental emosional remaja. Hasil penelitian ini sejalan dengan penelitian 
yang dilakukan oleh Yuldawati (2008) bahwa rata-rata remaja yang memiliki perilaku seksual berisiko adalah remaja di usia pertengahan dan usia tersebut dapat mempengaruhi perilaku remaja. Remaja berusia 16 tahun merupakan remaja usia pertengahan, dimana secara psikososial mampu membangun nilai, norma dan moralitas serta mampu berpikir independen terhadap permasalahan dirinya (Santrock, 2007). Remaja usia pertengahan memiliki kemauan yang sulit dikompromikan sehingga mungkin berlawanan dengan kemauan orang tua. Hal ini menyebabkan remaja cenderung melepaskan diri dari ikatan orang tuanya dan lebih banyak menghabiskan waktu dengan teman sebaya. Berbeda dengan remaja usia akhir yang memiliki emosi lebih stabil, minat dan konsentrasi semakin baik dan kemampuan menyelesaikan masalah sudah mulai berkembang.

Survei yang dilakukan Federasi Kesehatan Mental Indonesia (Fekmi) menemukan bahwa para remaja telah mengenal tempat maksiat, perilaku minum minuman keras, merokok, dan narkoba yang sudah muncul pada remaja awal dan terus berlanjut hingga remaja menengah dan remaja akhir. Berdasarkan hasil penelitian diperoleh arah korelasi antara umur remaja dengan masalah mental emosional adalah arah positif. Arah korelasi ini menunjukkan bahwa semakin remaja mendekati usia remaja akhir, maka akan semakin berisiko untuk mengalami masalah mental emosional. Hasil penelitian didapatkan rata-rata remaja berada di usia remaja pertengahan, dan risiko terjadinya masalah mental emosional akan terus berlanjut hingga remaja mencapai usia remaja akhir.

Hal ini juga sesuai dengan tahap perkembangan Eric-Erikson yang dikemukan oleh Nurdin (2011) dan Yusuf (2011) bahwa remaja merupakan masa berkembangnya krisis identitas. Yaitu masa dimana individu harus memutuskan siapa dia dan apa yang dia dilakukan, akibatnya remaja sangat peka terhadap stress, frustasi dan konflik (Nurdin, 2011). Dari uraian diatas dapat disimpulkan bahwa remaja usia pertengahan dengan emosi yang belum stabil lebih berisiko mengalami masalah mental mental emosional.

\section{Hubungan Jenis Kelamin Responden dengan Masalah Mental Emosional Remaja}

Hasil analisis menunjukkan tidak ada hubungan antara jenis kelamin dengan masalah mental emosional remaja. Hal ini sejalan dengan penelitian yang dilakukan oleh Nurmagupta (2014) bahwa tidak ada perbedaan perilaku yang signifikan antara remaja laki-laki dan perempuan di Yogyakarta. Tidak adanya hubungan antara jenis kelamin dengan masalah mental emosional remaja ini juga ditunjukkan oleh hasil penelitian yang dilakukan oleh Cefai (2009) yang menunjukkan hasil baik remaja laki-laki dan remaja perempuan sama-sama memiliki masalah psikososial. Penelitian Cefai (2009) menunjukkan bahwa anak laki-laki mengalami masalah perilaku dan anak perempuannya mengalami masalah emosional. Dimana masalah perilaku dan masalah emosional merupakan kriteria pada masalah mental emosional pada remaja. Remaja laki-laki dan remaja perempuan sama-sama mengalami masalah mental emosional.

Berdasarkan hasil penelitian ini dapat dianalisa bahwa tidak adanya hubungan antara jenis kelamin dengan masalah mental emosional remaja karena pertumbuhan dan perkembangan remaja dipengaruhi oleh hormon. Sesuai dengan teori yang disampaikan oleh Potter (2005) terdapat dua jenis hormon yang berpengaruh pada perkembangan remaja yaitu hormon androgen yang mempengaruhi perkembangan remaja laki-laki dan hormon estrogen yang mempengaruhi remaja perempuan.Produksi hormon akan meningkat selama masa perkembangan remaja. Jumlah kadar estrogen dan testosteron menimbulkan perasaan mudah tersinggung, tegang, gelisah dan bermusuhan. Dari uraian diatas dapat disimpulkan bahwa jenis kelamin tidak ada hubungannya dengan masalah mental emosional remaja.

\section{Hubungan Pendidikan Responden dengan Masalah Mental Emosional Remaja}

Hasil penelitian menunjukkan tidak adanya hubungan pendidikan remaja dengan masalah mental emosional remaja.Penelitian ini sejalan dengan penelitian yang dilakukan oleh Cefai (2009) yang menunjukkan bahwa tidak ada perbedaan masalah perilaku dan emosional pada anak sekolah dasar dengan anak sekolah menengah. Mereka sama-sama memiliki skor tinggi pada masalah hiperaktivitas, masalah perilaku, dan masalah emosional.

Berdasarkan hasil penelitian yang diperoleh terlihat bahwa semua anak remaja berisiko memiliki masalah mental emosional tanpa memandang tingkat pendidikannya, baik pendidikan rendah maupun pendidikan tinggi.Hal ini sesuai dengan data yang dilaporkan oleh Survei Data Kesehatan Indonesia (SDKI, 2012) bahwa remaja SMP, SMA, dan perguruan tinggi sama-sama berperilaku negatif seperti merokok, minum minuman beralkohol dan menggunakan obat terlarang. Data yang didapatkan dari 8.419 remaja, sebanyak 7.786 remaja yang berpendidikan SMP, SMA, dan perguruan tinggi menunjukkan perilaku negatif seperti merokok, minum minuman beralkohol.

Dari uraian diatas dapat disimpulkan bahwa pendidikan tidak ada hubungannya dengan masalah mental emosional remaja.semua remaja berisiko mengalami masalah mental emosional tanpa memandang tingkat pendidikan.

\section{Hubungan Pekerjaan Orang Tua dengan Masalah Mental Emosional Remaja}

Hasil penelitian didapatkan pekerjaan orang tua terbanyak adalah jenis pekerjaan formal (PNS dan 
Wiraswasta) dan ada hubungan antara pekerjaan orang tua dengan masalah mental emosional remaja. Penelitian ini sejalan dengan penelitian yang dilakukan oleh Agustina (2012) yang menunjukkan hasil bahwa ada pengaruh yang signifikan dari pekerjaan orang tua terhadap perilaku remaja.Faktor yang mempengaruhi perilaku remaja diantaranya pekerjaan orang tua. Pekerjaan orang tua akan mempengaruhi perkembangan nilai, moral, sikap, dan perilaku individu.

Hal ini didukung oleh teori yang dikemukakan oleh Soekanto (2003) dalam Asmadi (2008), lingkungan pekerjaan orang tua akan mempengaruhi bagi pembentukan sikap, reaksi, dan kepribadian orang tua. Intensitas waktu kerja orang tua sebagai PNS dan Swasta yang mulai dari pagi hari hingga sore hari dapat saja membuat orang tua kelelahan dan kurangnya kontrol terhadap anaknya, namun hal ini tergantung pada sikap dan rasa tanggung jawab orang tua dalam mendidik anaknya. Saliman (2010) berpendapat bahwa kurang adanya perhatian dan kontrol dari orang tua terhadap perilaku anaknya dapat menyebabkan terjadi masalah dan gangguan perilaku pada anak, sehingga tak jarang anak juga berisiko mengalami masalah mental emosional.

Berdasarkan hasil penelitian yang diperoleh dapat disimpulkan bahwa orang tua yang memiliki jenis pekerjaan formal dan kurang interaksi dengan anaknya dapat menyebabkan terjadinya masalah mental emosional pada remaja.Hal ini disebabkan oleh kurangnya waktu dan keinginan serta kesadaran orang tua untuk berinteraksi dengan anak remajanya, sehingga kurang terjalin komunikasi yang baik antara orang tua dengan remaja. Akibatnya anak akan sering keluar rumah berkumpul dengan teman sebaya mereka, sehingga tak jarang remaja terpengaruh oleh perilaku negatif yang dilakukan oleh teman sebanya dan tak jarang remaja rentan mengalami masalah mental emosional.

\section{Hubungan Pendidikan Orang Tua dengan Masalah Mental Emosional Remaja}

Hasil analisis didapatkan ada hubungan antara pendidikan orang tua dengan masalah mental emosional remaja. Penelitian ini sejalan dengan penelitian yang dilakukan oleh Ariani (2006) yang menunjukkan bahwa ada hubungan antara pendidikan orang tua dengan perilaku remaja. Berdasarkan hasil penelitian diperoleh pendidikan orang tua terbanyak adalah perguruan tinggi namun masalah mental emosional remaja terbanyak kategoriborderline.Berdasarkan hasil penelitian tersebut dapat dianalisa bahwa meskipun orang tua berpendidikan tinggi, namun remaja mereka masih beresiko mengalami masalah mental emosional.

Hal ini dapat saja terjadi karena orang tua yang bependidikan tinggi lebih mementingkan karirnya yang terus meningkat karna level pendidikan.Syarat peningkatan karir yang dilihat dari tingkat pendidikan membuat orang tua lebih mementingkan karirnya dan mengejar pendidikannya dari pada keluarganya. Hal ini sejalan dengan teori yang diungkapkan oleh Yusuf (2011) bahwa orang tua yang berpendidikan tinggi lebih berorientasi kepada karir dari pada keluarga. Hal ini terjadi karena adanya pergeseran pola hidup dan perubahan yang serba cepat.Perubahan-perubahan yang serba cepat sebagai konsekuensi globalisasi, modernisasi, industrialisasi, dan iptek telah mengakibatkan perubahan pada nilai-nilai kehidupan sosial dan budaya. Perubahan itu antara lain pada nilai moral, agama, dan pendidikan anak dirumah. Sehingga mempengaruhi dalam mendidik anak dan remaja dalam keluarga misalnya memberikan kelonggaran kepada anak remajanya.

Dari uraian diatas dapat disimpulkan bahwa orang tua yang memiliki pendidikan tinggi namun hanya berorientasi pada karir tetapi bukan kepada keluarga akan dapat menyebabkan remajanya beresiko mengalami masalah mental emosional.

\section{Hubungan Status Sosial Ekonomi dengan Masalah Mental Emosional Remaja}

Hasil penelitian ini didapatkan bahwa lebih dari setengah orang tua responden memiliki tingkat sosial ekonomi rendah. Penelitian ini sejalan dengan penelitian yang dilakukan oleh Hoskins (2014) yang menunjukkan bahwa status sosial ekonomi mempengaruhi fungsi psikologis dan fungsi sosial emosional remaja. Penelitiannya menunjukkan bahwa orang tua dengan tingkat sosial ekonomi tinggi lebih mengontrol dan membatasi perilaku anaknya dibanding dengan ibu yang memiliki tingkat sosial ekonomi rendah.

Berdasarkan hasil penelitian tersebut dapat dianalisa bahwa pola asuh dengan keluarga yang memiliki tingkat sosial ekonomi rendah dikaitkan dengan hasil perilaku remaja yang negatif.Akibatnya anak remaja mereka dilaporkan mengalami masalah emosional dan perilaku. Sehingga remaja dengan orang tua yang memiliki tingkat sosial ekonomi rendah berisiko tinggi mengalami masalah mental emosional.Orang tua yang mengalami tekanan ekonomi atau perasaaan tidak mampu mengatasi masalah finansialnya cenderung menjadi depresi dan mengalami konflik keluarga yang akhirnya mempengaruhi masalah remaja seperti masalah mental emosional. Hal ini sejalan dengan teori yang diungkapkan oleh Yusuf (2011) yang mengatakan bahwa orang tua dengan kelas sosial dan status ekonomi bawah cenderung sangat menekankan kepatuhan dan respek terhadap otoritas, lebih keras dan otoriter, kurang memberikan alasan kepada anak, dan kurang bersikap hangat dan memberi kasih sayang kepada anak. Dari uraian diatas dapat disimpulkan bahwa orang tua yang memiliki tingkat sosial ekonomi rendah beresiko mengalami masalah mental emosional pada anak remajanya. 


\section{Variabel Dominan yang Mempengaruhi Masalah Mental Emosional Remaja}

Penelitian ini menghasilkan variabel yang paling dominan mempengaruhi masalah mental emosional remaja yaitu pola asuh permisif.Hal ini dapat dilihat dari koefesien korelasi variabel pola asuh permisif sebesar 0,341 yang lebih besar dari koefesien korelasi pola asuh demokratis $(-0,222)$, umur remaja $(0,146)$, dan pekerjaaan orang tua $(-0,206)$.

Pola asuh permisif digambarkan dengan ketidakpedulian orang tua terhadap perkembangan anak remajanya. Cenderung memberikan segala keinginan yang remaja mau atau bahkan tidak mau tahu dengan apa yang menjadi keinginan anak remajanya (Santrock, 2007). Anak akan merasa lebih bebas dalam menentukan apa yang menjadi keinginannya. Remaja akan merasa lebih leluasa dalam bergaul maupun dalam menyikapi lingkungan luar. Anak yang tumbuh tanpa kekangan biasanya mempunyai daya kreativitas yang cukup tinggi. Namun disisi lain anak yang tidak mempunyai kekangan akan bebas menentukan pilihan yang dianggapnya baik untuk dirinya. Remaja memiliki keinginan yang tinggi untuk mencoba hal-hal baru dan terkadang hal ini tidak diimbangi dengan pengetahuan yang cukup baik dengan dampak maupun resiko bagi dirinya sendiri (Konnie, 2013).

Dari uraian diatas dapat disimpulkan bahwa pola asuh permisif sangat berpotensi menyebabkan masalah mental emosional remaja, untuk dapat menghindari masalah mental emosional tersebut diharapkan orang tua dapat mengurangi sikap permisif kepada anak remajanya.

\section{SIMPULAN}

Pola asuh otoriter, dan demokratis dapat terus dipertahankan oleh orang tua dalam mendidik anaknya agar anak remajanya terhindar dari resiko terjadinya masalah mental emosional, namun pola asuh permisif tidak dapat dijadikan sebagai pola asuh yang dominan dalam mendidik anak

\section{DAFTAR PUSTAKA}

Alves, D.; Roysamb, E.; Oppedal, B.; Zachrison, H. (2011). Emotional Problems in Preadolescent in Norway: The Role of Gender, Ethnic Minority Status and Home-and School-Related Hassles. Journal of Child and Adolescent Psychiatry and Mental Health

Anggoro, M. (2013). Polisi Pekanbaru Buru Geng Motor hingga kesekolah. Antara news. http://www.antaranews.com. Diperoleh tanggal 16 Maret 2015

Batubara (2010). Adolescent Development (Perkembangan Remaja), Jakarta, Sari Pediatri

Cefai, Carmel., Cooper, Paul., Camilleri, Liberato. (2009). Social Emotional and Behaviour Difficulties in Maltese Primary School,
Proceedings. International Conference on Primary Education, University of Malta

Diananta, Gita Soraya. (2012). Perbedaan Masalah Mental Emosional Berdasarkan Latar Belakang Pendidikan Agama. Universitas Diponegoro

Dewi, Ari Pristiana. (2012). Tesis : Hubungan Karakteristik Remaja, Peran teman Sebaya dan Paparan Pornografi dengan Perilaku Seksual Remaja di Kelurahan pasir Gunung Selatan Depok. Universitas Indonesia

Elizabet., Magaret. (2010). Foundation of Phychiatric Mental Health Nursing, Canada, Elsevier

Fontaine, Karen Lee. (2009). Mental Health Nursing, New Jersey, Pearson Education

Goodman, Robert. (2004). The Strenghts and Difficulties Questionnaire : A Research Note. Journal of Child Psychology and Psychiatry

Hartanto. F. Selina. H. (2011). Prevalensi Masalah Mental Emosional Pada Remaja di Kota Semarang dengan Menggunakan 2011 : Kuesioner Kekuatan dan Kesulitan (SDQ), Pedriatica Indonesia Volume 51 (suppl 4) juli Jakarta

Hoskins, Donna Hancock. (2014). Consequence of Parenting on Adolescent Outcomes, Journal of Societies, USA

Huver, Rose M.E., Otten, Roy., Vries, Engels. (2010). Personality and parenting Style in Parents of Adolescent, Journal of Adolescence, Elsevier

Kharie, Runi Rahmatia., Pondang, Linnie., Lolong, Jill. (2014). Hubungan Pola Asuh Orang Tua dengan Perilaku Merokok Pada Anak laki-Laki Usia 1517 Tahun di Kelurahan Tanah Raja Kota Ternate. Jurnal Universitas Sam Ratulangi Manado

Kuesioner Kekuatan dan Kesulitan $(S D Q)$ :http://www.SDQinfo.org. Diperoleh tanggal 02 Maret 2015

Konnie, MM \& Alfred, K. ( 2013). Influence of Parenting Styles on the Social Development of Children. Academic Journal of Interdisciplinary Studies. Vol 2 No. 3

Koskelainen, Merja. (2008). The Strengths and Difficulties Questionnaire Among Finnish SchoolAged Children and Adolescent, Department of Child Psychiatry, Finland

Kusuma, Rig. (2004). Perkembangan Kognitif pada Remaja, Jakarta, CV.Sagung Seto

Kusuma, Tirta. (2014). Perbedaan Masalah Mental Emosional Pada Remaja Yang Bermain Video Game Aksi dan Non Aksi.Jurnal Media Medika Muda. Universitas Diponegoro

Laksmiwati, I. (2009). Transformasi Sosial dan Perilaku Reproduksi Remaja. Google Cendekia. Diakses tanggal 28 Juli 2015

Lindawati.(2011). Faktor-Faktor Yang Mempengaruhi Perilaku Merokok Siswa-Siswi SMP di Daerah Jakarta Selatan Tahun 
2011.www.poltekkesjakarta.ac.id. Diakses tanggal 11 Juli 2015

McGue. M. Iacono WG. (2005). The Association of Early Adolescent Problem Behaviour with Adult Psychopathology. The American Jurnal of Psychiatry.

http://ajp.psychiatryonline.org/article.aspx?volum e162\&page $=1118$. Diperoleh tanggal 26 Februari 2015

Mutiah, Diana. (2010). Psikologi Bermain Anak Usia Dini, Edisi Pertama, Jakarta, Kencana

Nurdin, Adnil Edwin. (2011). Tumbuh Kembang Perilaku Manusia, Jakarta, EGC

Nurihsan, J.; Agustin, M. (2011). Dinamika Perkembangan Anak dan Remaja, Bandung, Refika Aditama

Nurmagupta, Deasti. (2014). Tesis : Hubungan Pola Asuh Dengan Perilaku Seksual Beresiko pada Remaja di Kecamatan Bundong, Kabupaten Bantul DIY. Keperawatan Universitas Indonesia

Pandia, Veranita. (2014). Instrumen Deteksi Dini Masalah Mental emosional pada Anak dan Remaja. Diperoleh dari http://muazarpsikolog.com/wpcontent/uploads/2014/08/Instrumen-Deteksi-DiniFinal.pdf. diakses tanggal 20 Februari 2015

Putri, Devi WH. (2014). Hubungan Durasi dan Frekuensi Bermain Video Game dengan Masalah Mental Emosional Pada Remaja. Universitas Diponegoro

Putri, Dewi Eka., Sasmita, Heppi., Yudia, Ceria. (2014). Hubungan Pola Asuh Orang Tua Dengan Pencegahan Penyalahgunaan Napza pada Siswa/Siswi di SMA Adabiyah Padang Tahun 2014. Proceeding, Konferensi nasional IX keperawatan Kesehatan Jiwa

Richter, J. (2011). The Strengths and Difficulties Questionnaire (SDQ) - Self Report.An Analysis of Its Structure in a Multiethnic Urban Adolescent Sample.Journal of Child Psychology and Psychiatry.

Sadock, Benjamin J. (2010). Kaplan \& Sadock Buku Ajar Psikiatri Klinis Edisi 2, Jakarta, EGC

Santrock. J. W. (2003). Adolescent Perkembangan Remaja (Alih Bahasa Shinto B. Adelar \& Sherly Saragih), Jakarta, Erlangga

Senjaya, P. (2011). Good Parents Bad Parents, Jakarta, Gramedia Pustaka Utama

Soedomo, Hadi. (2003). Pendidikan (Suatu Pengantar), Surakarta, UNS Press

Soekanto, S. (2003).Sosiologi Suatu Pengantar, Jakarta, Rajawali Press

Stadler, C.; Feifel, J.; Rohrmann, S.; Vermeiren, R.; Poustka, F. (2010). Peer-Victimization and Mental Helath Problems in Adolescent : Are Parental and School Support Protective?. Journal of Child Psychiatry Hum Dev
Stuart, Gail, W. (2013). Principles and Practise of Psychiatric Nursing Ed.10, Canada, Evolve

Tam, Cai-Lian., Chong, Amanda., Kadirvelu, Amudha,. Khoo, Yoon-Ting. (2012). Parenting Style and Self Efficacy of Adolescent : Malaysian Scenario, Global Jorunal of Human Social Science Vol 12.

Tarwoto. (2010). Kesehatan Remaja, Jakarta, Salemba Medika

Tjie, Lie Tjun, dkk. (2014). Perilaku Prososial Masyarakat Manado di Desa Watu Pinawetengan dan Kema II. Universitas Pelita Harapan. Diakses tanggal 30 April 2015

Townsend, Mary C. (2009). Psychiatric Mental Health Nursing : Consept of Care in Evidence-Based Parctice, USA, Davis Company

Turner, EA.; Chandler, M.; Heffer, RW. (2009). The Influence of Parenting Styles, Achievement Motivation, and Self-Efficacy on Academic Performance in College Student. Journal of College Student Development

Ullebo, A., Obel, C. (2011). Screening for The Attention Deficit Hiperactivity Disorder Phenotype Using the Strength and Difficulties Questionnaire (SDQ). European Child and Adolescent Psychiatry

Utami, Dian Putri. (2012). Masalah Mental Emosional Pada Siswa SMP Kelas Akselerasi dan Reguler. Universitas Diponegoro

Wiguna. T. (2010). Masalah Kesehatan Mental Remaja di Era Globalisasi dalam The 2nd Adolescent Health National Symposia Current Challenges in Management. Departemen Ilmu Kesehatan Anak FKUI-RSCM

Yuldawati. (2008). Tesis : Hubungan Antara Polas Asuh Orang Tua dan Perilaku Seksual Pelajar SMA Negeri diKota Solok. Universitas Indonesia

Yusuf, Syamsu. (2011). Psikologi Perkembangan Anak dan Remaja, Bandung, PT. Remaja Rosdakarya 